\title{
KARAKTERISTIK MI BERBASIS TEPUNG UBI KAYU TERMODIFIKASI (MOCAF) YANG DIPERKAYA EKSTRAK WORTEL (DAUCUS CAROTA)
}

\section{CHARACTERISTIC OF MODIFIED CASSA VA FLOUR (MOCAF) NOODLE ENRICHED WITH CARROT (DAUCUS CAROTA) EXTRACT}

\author{
Ardiba Rakhmi Sefrienda'), Dini Ariani ${ }^{1)}$, Ahmad Fathoni' ${ }^{2)}$ \\ 1) Research Division for Natural Product Technology, Indonesian Institute of Sciences (LIPI) \\ 2) Research Centre for Biotechnology, Indonesian Institute of Sciences (LIPI) \\ E-mail: ardiba2@gmail.com
}

Diterima : 10-12-2019

Direvisi : 20-02-2020

Disetujui : 12-05-2020

\begin{abstract}
ABSTRAK
Saat ini, kebutuhan tepung terigu untuk industri pangan seperti industri mi sangat tinggi. Oleh karena itu, pengembangan bahan baku lokal untuk produksi mi menjadi sangat penting mengingat tepung terigu merupakan komoditas impor dan tingkat konsumsi mi terus meningkat setiap tahun. Tujuan penelitian ini adalah mengetahui karakter mi kering non terigu yang dibuat dari tepung ubi kayu termodifikasi atau mocaf kaya beta karoten dengan penambahan ekstrak wortel yang kemudian disebut mi wortel mocaf kaya beta karoten. Analisis morfologi (struktur), sifat fisik (warna, kuat patah, cooking loss, tensile strength, dan water absorption), sifat kimia (proksimat), dan sensoris dilakukan dengan mi wortel mocaf komersial yang masih mengandung terigu sebagai kontrol. Analisa statistik independent sample $T$ Test digunakan untuk melihat perbedaan nyata dari kedua produk. Hasil pengujian morfologi menunjukkan bahwa mi wortel mocaf kaya beta karoten memiliki struktur padat dan mi wortel mocaf komersial lebih berongga. Penilaian kuantitatif terhadap warna menggunakan chromameter menunjukkan bahwa mi mocaf kaya beta karoten berwarna lebih merah dan kuning berdasarkan nilai a dan $b$ yang lebih tinggi secara signifikan $(P<0,05)$ dibandingkan mi wortel mocaf komersial. Kuat patah, cooking loss dan kesukaan warna tidak berbeda signifikan $(P<0,05)$ terhadap kontrol mi wortel mocaf komersial. Namun hasil pengujian tensile strength, water absorption, kesukaan rasa, aroma, kenampakan, kekenyalan, dan keseluruhan mi wortel mocaf kaya beta karoten masih lebih rendah secara signifikan dibanding mi wortel mocaf komersial.
\end{abstract}

Kata kunci: Mi, mocaf, non gluten, pangan lokal, ubi kayu

\begin{abstract}
Nowadays, the need of food industry of wheat flour for food industry such as noodle industry is very high. Therefore, the utilization and development of local commodity for noodle production becomes crucial because wheat flour is an imported commodity and in fact that the consumption rate for noodle is increasing every year. This study aimed to characterise non-wheat dried noodles using high beta carotene modified cassava flour (mocaf) supplemented with carrot extract. Analysis of morphological structure, physical, chemical, and sensory properties were done and commercial wheat based mocaf carrot noodles was used as a control. Significance between two products was tested using simple $t$ test statistic analysis. The result of morphological test showed that the high beta carotene carrot noodles had a solid structure compared to the commercial. A quantitative assessment of colours using chromameter showed that high beta carotene noodle mocaf had more red and yellow compared to commercial noodles. There was no significant different $(P>0,05)$ in fracture strength, cooking loss and color delight are similar to the commercial one. However, it was found that the tensile strength, water absorption, taste, aroma, smell, elasticity, and overall noodle carrots mocaf rich beta carotene was significantly lower than the commercial mocaf carrot noodles.
\end{abstract}

Keywords: noodles, mocaf, local food, cassava 


\section{PENDAHULUAN}

7 mpor gandum atau tepung terigu sebagai sumber karbohidrat meningkat sebesar 1 juta ton dari tahun 2016 ke 2017 (Anonima , 2018). Hal ini dikarenakan makin besarnya kebutuhan masyarakat akan gandum, namun Indonesia sebagai negara tropis tidak cocok untuk budidaya gandum. Di Indonesia, tepung terigu digunakan dalam pembuatan sebagian besar makanan olahan kaya karbohidrat seperti mi, roti, bakwan, martabak, dan lainnya. Untuk produk mi sendiri, Indonesia merupakan salah satu negara dengan tingkat konsumsi mi tertinggi kedua setelah China, yang hampir mencapai 12.5 milyar bungkus mi pada tahun 2018 (Anonim ${ }^{b}$, 2018). Tingginya tingkat konsumsi mi berbanding lurus dengan tingkat kebutuh tepung terigu karena hingga saat ini bahan dasar pembuatan mi masih menggunakan tepung terigu karena kandungan gluten dalam tepung terigu yang membuat karakter adonan menjadi elastis pada saat proses pembuatan mi. Hal ini juga mengakibatkan ketergantungan negara terhadap impor tepung terigu semakin tinggi.

Di sisi lain, kandungan gluten pada tepung terigu memiliki dampak negatif bagi kesehatan terutama bagi penderita autis dan alergi pada penderita penyakit celiac. Pada penderita penyakit celiac, interaksi antara diet yang mengandung gluten dengan sistem imun di usus dapat menyebabkan diare, steatorea, penurunan berat badan karena malabsorbsi, anemia, osteoporosis, dermatitis herpetiormis, gejala neurologi, dan hipoplasia enamel gigi (Gujral et al., 2012). Oleh karena itu, pengembangan bahan baku lokal untuk produksi tepung pengganti tepung terigu dan mi sangat penting untuk terus dilakukan sehingga dapat mendukung tingkat kebutuhan tepung dan produk mi dalam negeri yang terus mengalami peningkatan. Pemanfaatan sumber daya lokal seperti tepung sukun, kentang, atau tepung mocaf menjadi makanan olahan seperti mi (Afifah dan Ratnawati, 2017; Biyumna et al., 2017; Kang et al., 2017) akan mengurangi ketergantungan negara terhadap impor tepung terigu.

Salah satu sumber daya lokal Indonesia yang telah dikembangkan untuk produksi tepung pengganti tepung terigu adalah tepung ubi kayu termodifikasi atau modified cassava flour (mocaf). Mocaf adalah tepung ubi kayu yang pada proses pembuatannya mengalami modifikasi (Herawati, 2011). Bakteri asam laktat adalah bakteri penghasil enzim yang umum digunakan pada produksi tepung mocaf karena kemampuannya menghasilkan enzim pektinolitik dan sellulolitik yang dapat menghancurkan dinding sel ubi kayu serta menghidrolisis pati menjadi asam-asam organik (Subagio et al., 2008). Modifikasi pati dilakukan untuk memperbaiki karakteristik yang tidak dikehendaki pada kondisi $\mathrm{pH}$, suhu, dan tekanan tertentu (Putri et al., 2018). Tepung mocaf memiliki karakter fisik dan kimia yang lebih baik dibandingkan tepung ubi kayu biasa dan dapat menggantikan penggunaan tepung terigu pada pembuatan berbagai pangan olahan. Karakter tepung mocaf dipengaruhi beberapa faktor salah satunya yaitu jenis ubi kayu yang digunakan. Setiap jenis ubi kayu memiliki potensi karakter yang berbeda-beda sehingga pemilihan jenis ubi kayu yang tepat menjadi penting agar produk mocaf yang dihasilkan memiliki karakter yang sesuai dengan produk pangan yang akan dibuat termasuk untuk produk mi.

Mi berbahan dasar tepung mocaf telah dikembangkan untuk kebutuhan akan produk mi yang rendah atau bebas gluten. Penambahan ekstrak sayur seperti ekstrak brokoli, wortel, atau bayam dilakukan untuk menambah kandungan mikronutrien seperti beta karoten pada ekstrak wortel. Pengembangan mi wortel mocaf komersial masih belum $100 \%$ bebas tepung terigu sehingga masih mengandung gluten. Penelitian ini bertujuan mengetahui karakter mi wortel mocaf tanpa penambahan terigu dengan menggunakan mocaf kaya beta karoten yang dikembangkan oleh Pusat Penelitian Bioteknologi Lembaga Ilmu Pengetahuan Indonesia (LIPI), Cibinong, Jawa Barat, Indonesia. 


\section{METODE PENELITIAN}

\section{Alat dan Bahan}

Alat yang digunakan untuk membuat mi mocaf adalah mesin mi merek Bayoran Teknik. Bahan yang digunakan berupa tepung mocaf yang diproduksi oleh Pusat Penelitian Bioteknologi Lembaga Ilmu Pengetahuan Indonesia (LIPI), Cibinong, Jawa Barat. Tapioka, maizena, garam, wortel dan CMC dibeli di pasar di daerah Boyolali, Jawa Tengah. Mi mocaf komersial merek "Ayo" didapatkan dari UKM Putri 21 Gunungkidul, Yogyakarta.

\section{Pembuatan Tepung Mocaf Kaya Beta Karoten}

Tepung mocaf kaya beta karoten dibuat dari ubi kayu genotip Mentega 2 dengan metode (Fathoni et al., 2016). Satu kilogram ubi kayu dikupas dan dicuci bersih menggunakan air dan dipotong tipis menjadi chip. Potongan chip kemudian direndam dalam air yang mengandung bakteri asam laktat $0,1 \%$ selama 15 jam untuk proses fermentasi. Setelah itu, chip direndam dalam air yang berisi larutan sodium metabisulfit 0,3\% selama 30 menit. Chip ditiriskan dan dikeringkan selama 24 jam pada suhu $50^{\circ}$ C. Chip kemudian digiling menggunakan hammer mill kemudian dilakukan pengayakan dengan ukuran 80-100 mesh. Tepung mocaf kaya beta karoten disimpan pada suhu kamar dalam kemasan low density polyethylene (LDPE) yang dilapisi aluminum foil.

\section{Pembuatan Mi Wortel Mocaf Kaya Beta Karoten}

Pembuatan mi wortel mocaf mengacu pada pembuatan mi pada skala industri (Haryadi, 2014) dengan sedikit modifikasi. Pati tapioka dan maizena dicampur air ekstrak wortel kemudian digelatinisasi menggunakan kompor pada api kecil. Gel pati tapioka dan maizena kemudian dicampurkan dengan tepung mocaf kaya beta karoten, telur, STPP, CMC, dan garam. Adonan digiling hingga menjadi kalis dan pipih kemudian dipotong menjadi untaian mi menggunakan noodle maker. Mie kemudian dikukus pada suhu $95-100^{\circ} \mathrm{C}$ selama 20 menit. Mi kemudian dikeringkan menggunakan rumah pengering pada suhu sekitar $40^{\circ} \mathrm{C}$ selama 36 jam dengan kadar air akhir mi sekitar $12 \%$.

\section{Uji Morfologi dan Warna Tepung Mocaf dan Mi Wortel Mocaf}

Struktur morfologi tepung dan mi mocaf dianalisis dengan SEM (Scanning Electron Microscope) merek Hitachi SU-70, Jepang yang dioperasikan pada $5 \mathrm{kV}$ dengan perbesaran 1000x (tepung mocaf) dan 200x (mie mocaf). Pengujian warna menggunakan Chromameter Konica Minolta CR-400. Pengujian meliputi pengukuran tingkat kecerahan (L), warna merah (a), dan warna kuning (b).

\section{Uji Fisikokimia Mi Wortel Mocaf}

Pengujian fisik meliputi tensile strength, kuat patah dan pengujian kualitas masak. Tensile strength dan kuat patah menggunakan alat universal testing machine (UTM) merek Zwick SA/ 0.5 Universal Testing Machine pada kecepatan $10 \mathrm{~mm} / \mathrm{min}$ dan panjang sampel 30 $\mathrm{mm}$.

Pengujian kualitas masak meliputi penentuan waktu masak (cooking time), uji rehidrasi, cooking loss, dan peningkatan volume sesuai metode (AACC Internasional, 2010). Penentuan waktu masak dilakukan dengan merebus 20 gram mi kering ke dalam $300 \mathrm{ml}$ air suling sampai bagian tengah mi matang ditandai dengan tidak ada aroma dan tekstur mentah saat dikunyah. Uji rehidrasi dilakukan dengan menghitung selisih berat mi kering dan mi setelah perebusan sesuai waktu optimum pada uji masak. Penentuan cooking loss dilakukan dengan menguapkan air rebusan sehingga didapatkan filtrat yang merupakan residu/losses pada mi. Filtrat ditimbang sampai konstan pada oven $105^{\circ} \mathrm{C}$. Peningkatan volume dihitung dengan membandingkan volume mi kering dan mi setelah perebusan. 
Pengujian proksimat seusai dengan standar SNI 01-2891-1992 mengenai Cara Uji Makanan dan Minuman (BSN, 1992).

\section{Uji Sensoris}

Pengujian sensoris dilakukan menggunakan uji kesukaan dengan skala kesukaan pada parameter warna, kekenyalan, rasa, aroma, kenampakan, dan keseluruhan. Mi wortel mocaf kaya beta karoten dibandingkan dengan mi wortel mocaf komersial yang beredar di pasaran. Skala kesukaan yang digunakan adalah sebagai berikut:

1 : Amat sangat tidak suka

2 : Sangat tidak suka

3 : Tidak suka

4 : Agak tidak suka

5 : Biasa saja

6 : Agak suka

7 : Suka

8 : Sangat suka

9 : Sangat suka sekali (Carpenter et al., 2000)

\section{Analisis Statistik}

Data dianalisis menggunakan SPSS dengan metode analisis independent sample $T$ Test untuk mengetahui perbedaan nyata mi mocaf dengan dan tanpa penambahan terigu.

\section{HASIL DAN PEMBAHASAN}

\section{Uji Morfologi dan Warna Tepung dan Mi Wortel Mocaf}

Pengujian morfologi dan warna pada bahan baku diperlukan untuk mengetahui pengaruh bahan baku terhadap produk mi yang dihasilkan. Berdasarkan hasil pengujian SEM pada gambar 1, struktur butiran tepung mocaf kaya beta karoten dan tepung mocaf komersial (gambar 1a dan 1b) terlihat bulat dengan sebagian hancur menjadi serpihan. Morfologi tepung yang tidak bulat sempurna dipengaruhi oleh proses penggilingan dan pengayakan yang berpotensi merusak granula pati.

Pada analisis SEM mi mocaf, terlihat bahwa struktur mi mocaf kaya beta karoten (gambar 1c) sangat padat, berbeda dengan mi mocaf komersial (gambar 1d) yang masih terdapat rongga pada struktur mi yang dihasilkan. Struktur berongga pada mi mocaf komersial diduga dari kandungan gluten di dalamnya yang dapat menghidrasi adonan mi. $\mathrm{Hal}$ ini sesuai dengan hasil penelitian (Lucisano et al., 2012) yang melaporkan hasil pengamatan gambar SEM pasta gandum durum bergluten tampak berongga dan pasta beras tanpa gluten yang padat pada perbesaran 500 kali.
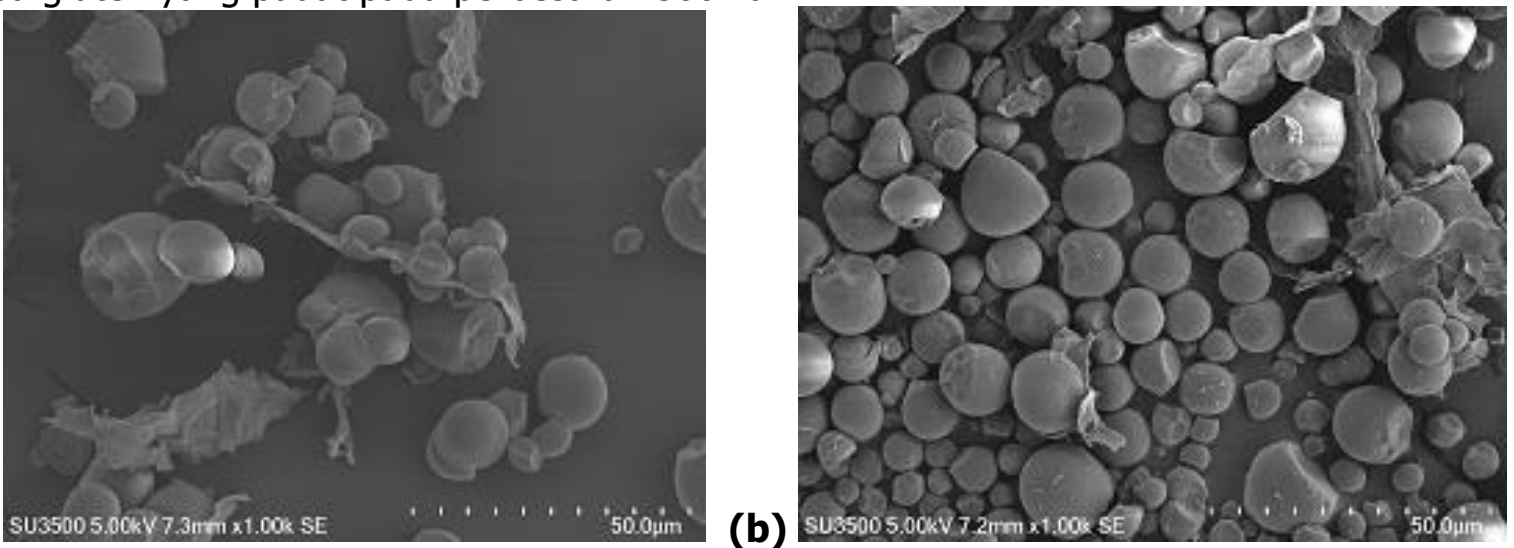

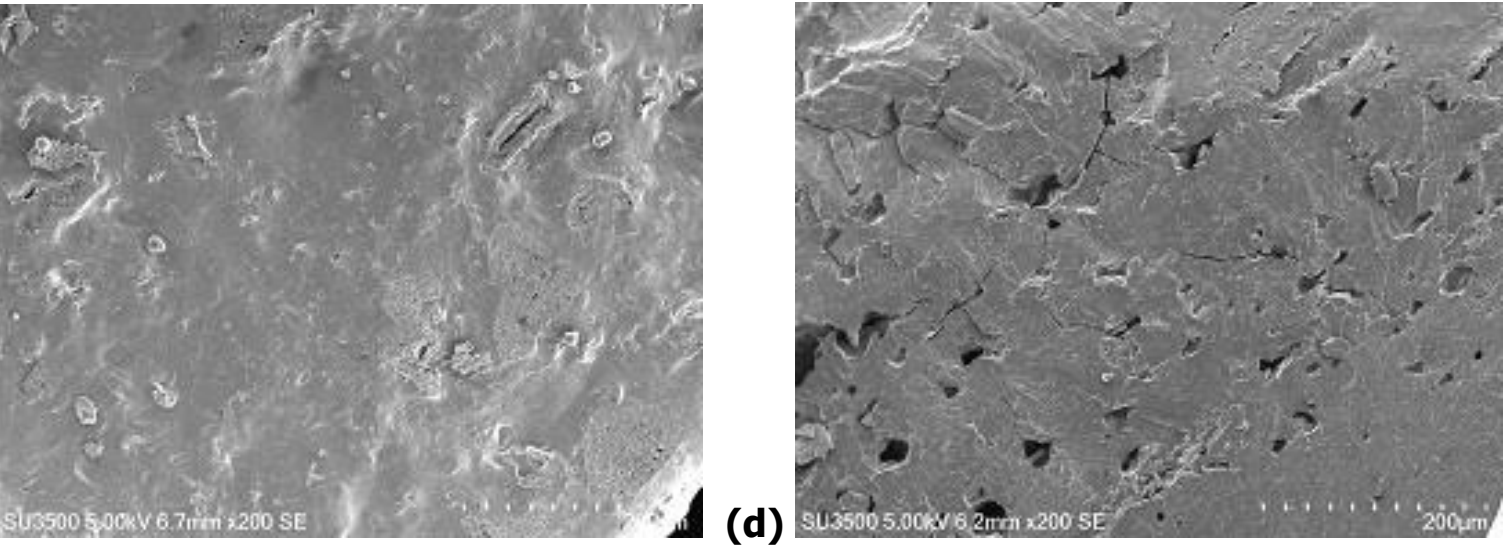

Gambar 1: Struktur SEM Tepung Mocaf Kaya Beta Karoten (a) dan Tepung Mocaf Komersial (b) pada perbesaran 1000x, Mi Wortel Mocaf Kaya Beta Karoten (c) dan Mi Wortel Komersial (d) pada perbesaran 200x.

Pengujian warna menggunakan Chromameter menunjukkan tepung mocaf kaya beta karoten berwarna lebih cerah dan kuning secara signifikan dibandingkan dengan tepung mocaf komersial. Bahan baku ubi kayu yang digunakan pada proses pembuatan tepung mocaf ini berbeda genotip sehingga karakteristik warna yang dihasilkan akan berbeda pula. Ubi kayu genotip mentega 2 yang digunakan pada tepung mocaf kaya beta karoten memiliki warna umbi kuning dengan kandungan beta karoten yang lebih tinggi dibandingkan ubi kayu genotip lain dan berpengaruh pada warna tepung yang dihasilkan, yaitu lebih cerah dan kuning.

Tabel 1. Hasil pengukuran warna tepung mocaf kaya beta karoten dan tepung mocaf komersial menggunakan chromameter

\begin{tabular}{lccc}
\hline \multicolumn{1}{c}{ Sampel } & L & A & B \\
\hline Tepung mocaf kaya beta karoten & $93,43 \pm 0,06^{\mathrm{b}}$ & $-0,03 \pm 0,05^{\mathrm{a}}$ & $7,4 \pm 0,1^{\mathrm{b}}$ \\
\hline Tepung mocaf komersial & $89,27 \pm 0,21^{\mathrm{a}}$ & $0,4 \pm 0^{\mathrm{b}}$ & $6,7 \pm 0,3^{\mathrm{a}}$ \\
\hline
\end{tabular}

Keterangan: Perbedaan huruf pada hasil analisis menunjukkan perbedaan yang signifikan pada derajat kepercayaan pada level 95\%. Setiap analisis dilakukan dengan 3x ulangan.

Hasil pengujian warna pada produk mi yang dihasilkan selaras dengan hasil pengujian warna tepung. Mi wortel mocaf komersial memiliki warna lebih cerah ditandai dengan nilai $\mathrm{L}$ yang berbeda signifikan. Selain itu, penambahan terigu pada mi wortel mocaf komersial menurunkan warna merah (a) dan kuning (b) pada produk mi sehingga pada hasil pengukuran nilai a pada mi wortel mocaf komersial lebih rendah secara signifikan dibanding nilai a dan $b$ pada mi wortel mocaf kaya beta karoten. Beta karoten merupakan senyawa antioksidan yang memiliki warna jingga, sehingga pada makanan dengan kandungan beta karoten yang tinggi, warna produk makananannya cenderung lebih jingga, ditandai warna merah (a) dan kuning (b) yang lebih tinggi dibandingkan dengan makanan tanpa beta karoten (Fathoni et al., 2016).

Tabel 2. Hasil pengukuran warna mi wortel mocaf kaya beta karoten dan mi wortel mocaf komersial menggunakan chromameter

\begin{tabular}{llll}
\hline Sampel & L & A & B \\
\hline Mi wortel mocaf kaya beta karoten & $47,8 \pm 0,46^{\mathrm{b}}$ & $7,17 \pm 0,4^{\mathrm{b}}$ & $27,37 \pm 1,19^{\mathrm{b}}$ \\
\hline Mi wortel mocaf komersial & $38,5 \pm 1,06^{\mathrm{a}}$ & $4,53 \pm 0,15^{\mathrm{a}}$ & $19,7 \pm 1,91^{\mathrm{a}}$ \\
\hline
\end{tabular}

Keterangan: Perbedaan huruf pada hasil analisis menunjukkan perbedaan yang signifikan pada derajat kepercayaan pada level 95\%. Setiap analisis dilakukan dengan 3x ulangan. 


\section{Perbandingan Uji Fisikokimiawi Mie Wortel Mocaf kaya Beta Karoten dengan Mi Wortel Mocaf Komersial}

Mi wortel mocaf komersial masih mengandung gluten karena diperlukan untuk menambah kemampuan elongasi (tensile strength) pada produk mi. Peningkatan kemampuan elongasi pada produk mi dapat juga melalui proses gelatinisasi pati seperti yang dilakukan pada pembuatan mi wortel mocaf kaya beta karoten. Namun berdasarkan pengujian tensile strength seperti yang tercantum pada tabel 2, nilai tensile strength produk mi wortel mocaf beta karoten lebih rendah secara signifikan dibanding mi wortel mocaf komersial. Subtitusi gluten dengan pati tergelatinisasi belum mampu menyamai tensile strength produk mi yang mengandung gluten.

Tabel 3. Uji fisik mi wortel mocaf kaya beta karoten dibandingkan dengan mi wortel mocaf komersial

\begin{tabular}{lcccccc}
\hline \multicolumn{1}{c}{ Sampel } & $\begin{array}{c}\text { Tensile } \\
\text { strength }\end{array}$ & Kuat patah & $\begin{array}{c}\text { Water } \\
\text { absoption (\%) }\end{array}$ & $\begin{array}{c}\text { cooking } \\
\text { loss }(\%)\end{array}$ & $\begin{array}{c}\text { Penambahan } \\
\text { volume (\%) }\end{array}$ & $\begin{array}{c}\text { Cooking } \\
\text { time }\end{array}$ \\
\hline $\begin{array}{l}\text { Mi wortel } \\
\text { mocaf kaya } \\
\text { beta karoten }\end{array}$ & $0,02 \pm 0^{\mathrm{a}}$ & $3,06 \pm 0,41^{\mathrm{a}}$ & $170,58 \pm 5,9^{\mathrm{a}}$ & $5 \pm 0,16^{\mathrm{a}}$ & $218,97 \pm 0,56^{\mathrm{a}}$ & $7: 13$ \\
\hline $\begin{array}{l}\text { Mi wortel } \\
\begin{array}{l}\text { mocaf } \\
\text { komersial }\end{array}\end{array}$ & $0,03 \pm 0^{\mathrm{b}}$ & $2,89 \pm 0,36^{\mathrm{a}}$ & $187,8 \pm 7,9^{\mathrm{b}}$ & $5,31 \pm 0,12^{\mathrm{a}}$ & $202,16 \pm 10,31^{\mathrm{a}}$ & $5: 05$ \\
\hline
\end{tabular}

Keterangan: Perbedaan huruf pada hasil analisis menunjukkan perbedaan yang signifikan pada derajat kepercayaan pada level 95\%. Setiap analisis dilakukan dengan 3x ulangan.

Kuat patah sampel mi wortel mocaf kaya beta karoten dan mi wortel mocaf komersial tidak berbeda signifikan walaupun berbeda karbohidrat penyusun dan jenis ubi kayu yang digunakan untuk tepung mocaf. Hal ini dapat dipengaruhi oleh struktur padat pada mi wortel mocaf kaya beta karoten seperti terlihat pada hasil analisa SEM pada gambar 1. Struktur padat ini membuat mi wortel mocaf kaya beta karoten memiliki kuat patah yang lebih tinggi dibanding mi wortel mocaf komersial. Kuat patah dengan nilai lebih tinggi menunjukkan bahwa sampel mi tidak gampang hancur selama proses distribusi.

Water absorption, cooking loss, dan penambahan volume merupakan aspek fisik yang menjadi parameter kualitas pada proses pembuatan mi. Kemampuan menyerap air harus tepat, karena apabila mi tidak dapat menyerap air dengan baik, maka proses pemasakan akan lama dan kurang efektif, tetapi bila kemampuan menyerap airnya terlalu tinggi, maka mi yang dihasilkan akan terlalu lembek. Cooking loss / kehilangan bahan saat pemasakan diusahakan seminimal mungkin. Kehilangan bahan pada mi non gluten dilaporkan sebesar 11,2\% sampai 27,38\% (Afifah dan Ratnawati, 2017). Kehilangan bahan dihitung dari berat endapan pada air sisa perebusan. Penambahan volume berkolerasi dengan penambahan air, namun bisa juga dipengaruhi adanya putih telur yang dapat mengembang selama proses penggilingan dan pengukusan (Bovskova dan Míková, 2011). Tidak ada perbedaan nyata pada cooking loss dan penambahan volume antara mi wortel mocaf kaya beta karoten dan mi wortel mocaf komersial. Namun pada water absorption dan cooking time didapatkan hasil yang berbeda signifikan. Hal ini disebabkan karena struktur mi wortel mocaf kaya beta karoten yang lebih padat dibanding mi wortel mocaf komersial sehingga kemampuan mnyerap airnya lebih sulit dan waktu pemasakannya lebih lama.

Pada pengujian proksimat mi wortel mocaf, didapatkan hasil bahwa kandungan protein, abu, dan karbohidrat mi wortel mocaf beta karoten lebih rendah dibanding mi wortel mocaf komersial. Sebaliknya, hasil pengujian lemak pada mi wortel mocaf kaya beta karoten memunjukkan hasil lebih tinggi secara signifikaan dibanding mi wortel mocaf komersial. Pada proses pembuatan mi mocaf kaya beta karoten, telur ditambahkan sebanyak sepertiga dari 
tepung mocaf yang digunakan. Hal ini bertujuan agar adonan tidak mudah patah saat dibentuk dan meningkatkan nilai gizi, terutama protein dan lemaknya.

Tabel 4. Uji proksimat mi wortel mocaf per 100 gram bahan (basis kering)

\begin{tabular}{lcccc}
\hline \multicolumn{1}{c}{ Sampel } & Lemak & Protein & Abu & Karbohidrat \\
\hline Mi wortel mocaf kaya beta karoten & $7,46 \pm 0,05^{\mathrm{b}}$ & $5 \pm 0,87^{\mathrm{a}}$ & $2,99 \pm 0,2^{\mathrm{a}}$ & $77 \pm 5,57^{\mathrm{a}}$ \\
\hline Mi wortel mocaf komersial & $0,11 \pm 0,01^{\mathrm{a}}$ & $10 \pm 1,5^{\mathrm{b}}$ & $9,89 \pm 1,19^{\mathrm{b}}$ & $80 \pm 3^{\mathrm{a}}$
\end{tabular}

Keterangan: Perbedaan huruf pada hasil analisis menunjukkan perbedaan yang signifikan pada derajat kepercayaan pada level 95\%. Setiap analisis dilakukan dengan 3x ulangan.

\section{Uji Kesukaan Mie Wortel Mocaf kaya Beta Karoten dengan Mi Wortel Mocaf Komersial}

Uji kesukaan dilakukan untuk mengetahui tingkat penerimaan konsumen terhadap produk mi mocaf yang dihasilkan. Penilaian panelis terhadap warna tidak berbeda signifikan yang berarti warna mi wortel mocaf kaya beta karoten dan mi wortel mocaf komersial diterima dengan sama baiknya oleh calon konsumen.

Tabel 5. Hasil uji sensoris mi wortel mocaf kaya beta karoten dibandingkan mi wortel mocaf komersial

\begin{tabular}{lllllll}
\hline Sampel & Warna & Kekenyalan & Rasa & Aroma & Kenampakan & Keseluruhan \\
\hline $\begin{array}{l}\text { Mi wortel } \\
\text { mocaf kaya } \\
\text { beta } \\
\text { karoten }\end{array}$ & $5,45 \pm 1,82^{\mathrm{a}}$ & $4,73 \pm 1,42^{\mathrm{a}}$ & $4,27 \pm 1,52^{\mathrm{a}}$ & $4,23 \pm 1,57^{\mathrm{a}}$ & $4,95 \pm 1,56^{\mathrm{a}}$ & $4,55 \pm 1,26^{\mathrm{a}}$ \\
\hline $\begin{array}{l}\text { Mi wortel } \\
\text { mocaf } \\
\text { komersial }\end{array}$ & $6,09 \pm 1,31^{\mathrm{a}}$ & $6,36 \pm 1,33^{\mathrm{b}}$ & $6,18 \pm 1,26^{\mathrm{b}}$ & $6,14 \pm 1,46^{\mathrm{b}}$ & $6,32 \pm 1,13^{\mathrm{b}}$ & $6,32 \pm 1,13^{\mathrm{b}}$ \\
\hline
\end{tabular}

Keterangan: Perbedaan huruf pada hasil analisis menunjukkan perbedaan yang signifikan pada derajat kepercayaan pada level 95\%. Setiap analisis dilakukan dengan 3x ulangan.

Berbeda dengan kenampakan, kekenyalan, rasa, aroma, dan keseluruhan pada sampel, penilaian panelis lebih rendah secara signifikan terhadap produk mi wortel mocaf kaya beta karoten dibandingkan dengan mi wortel komersial. Perbedaan kekenyalan dapat disebabkan dengan adanya kandungan gluten pada mi mocaf komersial menyebabkan tingkat kekenyalannya lebih familiar dan dapat diterima oleh panelis. Penerimaan rasa dan aroma yang lebih rendah disebabkan oleh penggunaan telur yang cukup banyak pada pembuatan mi wortel kaya beta karoten. Telur membuat adonan mi menjadi memiliki rasa dan aroma yang amis. Penggunaan telur sebenarnya ditujukan untuk memperbaiki tekstur mi yang dihasilkan sekaligus menambah nilai gizi pada produk mi. Akan tetapi, dengan hasil penerimaan konsumen yang lebih rendah dibandingkan produk komersial, maka penambahan telur pada proses pembuatan mi wortel mocaf kaya beta karoten perlu dikurangi jumlahnya. Penggunaan telur sebagai bahan pengikat pada proses pembuatan mi dapat disubstitusi oleh tepung konjac dan gum xanthan, dan berdasarkan uji efektifitas oleh (Diniyah et al., 2017), tepung konjac paling efektif secara penerimaan sensoris, karaketristik fisik, dan kimia mi. Walaupun demikian, secara keseluruhan produk mi mocaf kaya beta karoten ini memiliki prospek yang menjanjikan sebagai salah produk bebas gluten (non terigu) dan berbahan baku lokal. Pengembangan terhadap produk ini akan terus dilakukan untuk memperbaiki karakter produk terutama pada nilai uji sensori. 


\section{KESIMPULAN}

Pengujian morfologi pada mi wortel mocaf kaya beta karoten menghasilkan tekstur mi yang relatif lebih padat dibandingkan dengan mi wortel mocaf komersial. Hal ini berpengaruh pada water absorption yang lebih rendah dan waktu masak yang lebih lama. Penerimaan konsumen terhadap mi wortel mocaf kaya beta karoten masih lebih rendah dibandingkan dengan mi wortel mocaf komersial.

\section{UCAPAN TERIMA KASIH}

Penelitian ini didanai oleh Insinas Kemenristekdikti tahun 2018-2019. Terima kasih kepada UMKM Mekar Sari Boyolali, Putri 21 Gunungkidul, tim Insinas dan seluruh staf BPTBA LIPI Gunungkidul yang telah mendukung pembuatan, penyediaan pembanding, dan pengujian mi wortel mocaf kaya beta karoten.

\section{DAFTAR PUSTAKA}

AACC International. 2010. Approved Methods of Analysis, 11th Ed. Method 66-50.01. Pasta and Noodle Cooking Quality-Firmness. AACC International, St. Paul, MN, U.S.A. 2010.

Afifah, N. dan Ratnawati, L. 2017. Quality Assessment of Dry Noodles Made from Blend of Mocaf Flour, Rice Flour and Corn Flour Quality Assessment of Dry Noodles Made from Blend of Mocaf Flour, Rice Flour and Corn Flour. IOP Conf. Series: Earth and Environmental Science 101. https://doi.org/10.1088/1755-1315/.

Anonima. 2018. Berapa Impor Gandum Indonesia. Available at: https://databoks.katadata.co.id/datapublish/2018/02/22/berapa-impor-gandumIndonesia

Anonim ${ }^{\text {b }}$ 2018. Instant Noodle at the Glance. Avalaible at: https://instantnoodles.org/en/noodles/report.html

Biyumna., Listy, U., Windarti, W, S., dan Diniyah, N. 2017. Karakteristik Mie Kering Terbuat Dari Tepung Sukun (Artocarpus Altilis) Dan Penambahan Telur. Agroteknologi 11 (01): 23-34.

Bovskova, Helena, dan Míková, K. 2011. Factors Influencing Egg White Foam Quality. Czech Journal of Food Sciences 29 (4): 322-27. https://doi.org/10.17221/435/2010-cjfs.

BSN. 1992. (SNI) 01-2891-1992: Cara Uji Makanan Dan Minuman. Jakarta: Badan Standarisasi Nasional Indonesia.

Carpenter, Roland, P., David, H., Lyon, dan Terry, A. Hasdell. 2000. Guidelines for Sensory Analysis in Food Product Development and Quality Control. https://doi.org/10.1016/j.apmr.2013.08.017.

Diniyah, N., Setiawati, D., Windrati, W.S., dan Subagio, A. 2017. Karakterisasi Mi Mojang (Mocaf-Jagung) Dengan Perbedaan Jenis Dan Konsentrasi Bahan Pengikat. Jurnal Penelitian Pascapanen Pertanian 14 (2): 98-107.

Fathoni, A., Hartati, N.S., dan Mayasti, N.K.I. 2016. Minimalisasi Penurunan Kadar BetaKaroten dan Protein Dalam Proses Produksi Tepung Ubi Kayu. Pangan (25): 113-24.

Gujral, Naiyana, Freeman, H.J. dan Thomson, A.B.R. 2012. Celiac Disease: Prevalence, Diagnosis, Pathogenesis and Treatment. World J Gastroenterol 18 (42): 6036-59.

Haryadi. 2014. Noodle Technology. Yogyakarta: UGM Press.

Herawati, H. 2011. Potensi Pengembangan Produk Pati Tahan Cerna Sebagai Pangan Fungsional. Jurnal Litbang Pertanian 30 (1).

Kang, J., Lee, J., Choi, M., Jin, Y., Chang, D., Chang, Y.H., Kim, M., Jeong, Y., dan Lee, Y. 2017. Physicochemical and Textural Properties of Noodles Prepared from Different Potato Varieties. Preventive Nutrition and Food Science 22 (3): 246-50. https://doi.org/10.3746/pnf.2017.22.3.246. 
Lucisano, Mara, Cappa, C., Fongaro, L., dan Mariotti, M. 2012. Characterisation of GlutenFree Pasta through Conventional and Innovative Methods: Evaluation of the Cooking Behaviour. Journal of Cereal Science 56 (3): 667-75. https://doi.org/10.1016/j.jcs.2012.08.014.

Putri, Ariani, N., Herlina, dan Subagio, A. 2018. "Karakteristik Mocaf (Modified Cassava Flour) Berdasarkan Metode Penggilingan Dan Lama Fermentasi." Jurnal Agroteknologi 12 (01): 79. https://doi.org/10.19184/j-agt.v12i1.8252.

Subagio, A., Siti, W., Witono, Y., dan Fahmi, F. 2008. "Prosedur Operasi Standar (POS) Produksi MOCAF Berbasis Klaster." FTP UNEJ-SEAFAST CENTER IPB. 